\title{
Chapter 6 \\ Enzymatic Mismatch Cleavage and Agarose Gel Evaluation of Samples
}

\begin{abstract}
Denaturation and annealing of PCR products allows DNA strands with small sequence differences to hybridize together. The result is heteroduplexed molecules that are single stranded in polymorphic sequence locations, but double stranded elsewhere. These molecules are the substrates for cleavage by singlestrand-specific nucleases such as CEL I, crude Celery Juice Extract (CJE) containing CEL I, and other plant extracts containing single-strand-specific nucleases [Till et al. (Nucleic Acids Res, 32:2632-2641, 2004)]. Enzymatic cleavage initiates on a single strand and can result in double strand breaks. The products of cleavage can therefore be observed using native gel electrophoresis.
\end{abstract}

\subsection{Materials}

Consumables and equipment for enzymatic mismatch cleavage are listed in Table 6.1.

\subsection{Methods}

1. Prepare the following enzyme master mix on ice (calculated for five samples): $81.5 \mu$ l water

$15 \mu \mathrm{l} 10 \times$ CEL I buffer

$3.5 \mu \mathrm{l}$ CJE nuclease

2. Label four new PCR tubes with the sample name.

3. Combine $20 \mu \mathrm{l}$ of PCR product with $20 \mu \mathrm{l}$ of enzyme master mix. Pipette the mixture up and down to mix or vortex briefly followed by pulse centrifugation.

4. Incubate at $45^{\circ} \mathrm{C}$ for $15 \mathrm{~min}$ in a thermal cycler.

5. Place the reactions on ice, stop the reaction by adding $10 \mu \mathrm{l}$ of $0.25 \mathrm{M}$ EDTA per sample, and mix well by vortexing and centrifuge briefly (NOTE: Samples can be stored frozen for months before analysis). 
Table 6.1 Chemicals, enzymes, and equipment for enzymatic mismatch cleavage

\begin{tabular}{l|l}
\hline Material description & Examples of suppliers and specifications \\
\hline $10 \times$ CELI buffer & $\begin{array}{l}5 \mathrm{ml} 1 \mathrm{M} \mathrm{MgSO}, 100 \mu 110 \% \text { Triton X-100, } 5 \mathrm{ml} 1 \mathrm{M} \mathrm{Hepes} \\
(\mathrm{pH} 7.4), 5 \mu 120 \mathrm{mg} / \mathrm{ml} \text { bovine serum albumin, 2.5 ml 2 M KCl, } \\
37.5 \mathrm{ml} \text { water }\end{array}$ \\
\hline $\begin{array}{l}\text { Crude Celery Juice } \\
\text { Extract (CJE) }\end{array}$ & $\begin{array}{l}\text { See Till et al. (2004) for the preparation of enzyme and defining unit } \\
\text { activity. Chap. 7 provides a protocol for the preparation of single- } \\
\text { strand-specific nucleases from weedy plants }\end{array}$ \\
\hline $1 \mathrm{~kb}$ DNA ladder & Any general laboratory supplier \\
\hline $0.25 \mathrm{M}$ EDTA & $\begin{array}{l}\text { Prepared from ethylenediaminetetraacetic acid (EDTA) stock from } \\
\text { any general laboratory supplier }\end{array}$ \\
\hline $\mathrm{H}_{2} \mathrm{O}$ & Distilled or deionized and autoclaved \\
\hline $1.5 \mathrm{ml}, 2.0 \mathrm{ml}$ tubes & Any general laboratory supplier \\
\hline Thermocycler & e.g., Biorad C1000 Thermal cycler \\
\hline Microcentrifuge & Eppendorf Centrifuge 5415D \\
\hline Agarose gel equipment & Horizontal electrophoresis from any general laboratory supplier \\
\hline
\end{tabular}

6. Analyze the samples by electrophoresis using a $1.5 \%$ agarose gel. See Chap. 8 for example data.

Open Access This chapter is distributed under the terms of the Creative Commons Attribution Noncommercial License, which permits any noncommercial use, distribution, and reproduction in any medium, provided the original author(s) and source are credited.

\section{Reference}

Till BJ, Burtner C, Comai L, Henikoff S (2004) Mismatch cleavage by single-strand specific nucleases. Nucleic Acids Res 32:2632-2641 